УДК 634.8

DOI 10.30679/2219-5335-2019-4-58-72-87

ПРОДУКТИВНОСТЬ ВИНОГРАДА И КАЧЕСТВО ВИНА

В ЗАВИСИМОСТИ ОТ СХЕМЫ ПОСАДКИ И НАГРУЗКИ КУСТОВ ПОБЕГАМИ

Алейникова Галина Юрьевна

канд. с.-х. наук

ст. научный сотрудник

лаборатории управления

воспроизводством

в ампелоценозах и экосистемах

Павлюкова Татьяна Павловна

канд. с.-х. наук

Федеральное государственное бюджетное научное учреждение

«Северо-Кавказский федеральный научный иентр садоводства, виноградарства, виноделия», Краснодар, Россия

Разживина Юлия Анатольевна мЛ. научный сотрудник лаборатории виноградарства и виноделия

Анапская зональная опытная станщия виноградарства и виноделия - филиал Федерального государственного бюджетного научного учреждения «Северо-Кавказский федеральный научный иентр садоводства, виноградарства, виноделия», Aнапа, Россия

Изменения климатических условий в наибольшей степени оказывают влияние на такой вид деятельности, как сельское хозяйство в целом, и виноградарство в частности. Гармонизация факторов среды обитания, биологических особенностей растения и агротехнологии в ампелоценозе является основным условием эффективного производства
UDC 634.8

DOI 10.30679/2219-5335-2019-4-58-72-87

\section{PRODUCTIVITY OF GRAPES AND QUALITY OF WINE DEPENDING ON THE PLANTING SHEME AND SHOOTS LOAD OF BUSHES}

\author{
Aleynikova Galina Yuryevna \\ Cand. Agr. Sci. \\ Senior Research Associate \\ of Laboratory of Reproduction control \\ in the Ampelocenoses \\ and Ecological systems
}

Pavlukova Tatiana Pavlovna Cand. Agr. Sci .

Federal State Budget

Scientific Institution

"North Caucasian Federal

Scientific Center of Horticulture,

Viticulture, Wine-making»,

Krasnodar, Russia

Razzhivina Uylia Anatolyevna

Junior Research Associate

of Viticulture and Wine-making

Laboratory

Anapa Zonal Experimental Station of Viticulture and Wine-making Branch of Federal State

Budgetary Scientific Institution «North-Caucasus Federal

Scientific Center of Horticulture,

Viticulture, Wine-making»,

Anapa, Russia

Changes in climatic conditions have the greatest influence on such type of activity as agriculture in general, and viticulture in particular.

Harmonization of environmental factors, biological features of a plant and agrotechnology in ampelocenosis is the main condition for efficient grape production. In this regard, the study 
винограда. В связи с этим изучение влияния схемы посадки и нагрузки куста побегами на продуктивность винограда и качество вина является актуальным направлением исследований. Цель нашей работы - установление оптимальной схемы посадки и нагрузки куста сорта Рислинг рейнский побегами, выявление зависимости продуктивности, качественных показателей винограда и вина от применяемой агротехнологии в условиях локального изменения климата. Установлено, что в стрессовых условиях 2018 года насаждения с трёхметровыми междурядьями имели наибольшую хозяйственную продуктивность, а разреженные и уплотнённые наименьшую. Под влиянием погодных аномалий наблюдалось значительное уменьшение средней массы грозди и снижение урожая винограда в вариантах с междурядьем 2,5 и 3,5 метра.

Наиболее благоприятным для получения высококачественной продукции был 2017 год. В сравнении с 2016 годом разница в дегустационной оценке составляла от 0,1 (при схеме $3,0 \times 2,0$ м) до 0,7 (при схеме посадки 2,5×1,5 м). Наиболее стабильными по качеству были образцы из винограда с трёхметровыми междурядьями (7,8-8,0 баллов). Наиболее стабильное качество виноматериалов отмечено при схеме посадки кустов винограда 3,0×1,0 - диапазон колебаний при увеличении нагрузки куста побегами от 40 до 70 тыс. шт./га составил 0,1 балла с максимальным значением 8,0 при нагрузке 50 тыс. шт./га.

Ключевые слова: АМПЕЛОЦЕНОЗ, СХЕМА ПОСАДКИ, СОРТ ВИНОГРАДА, НАГРУЗКА КУСТОВ, ПРОДУКТИВНОСТЬ, КАЧЕСТВО of the influence of the planting scheme and the shoots load of the bush on the productivity of grapes and the quality of wine is a relevant area of research. The purpose of our work is to establish the optimal planting scheme and the schoots load of the Riesling grape bush, the identifying the dependence of productivity, quality indicators of grapes and wine on the applied agricultural technology in the context of local climate change. It was found that under stress conditions in 2018, the plantations with three-meter spacing had the highest economic productivity, and sparse and compacted plantations - the smallest. Under the influence of weather anomalies, a significant decrease in the average mass of the bunch and a decrease in the grape yield in the variants with a row spacing of 2.5 and 3.5 meters were observed. The most favorable for obtaining the high-quality products was 2017 . In comparison with 2016 , the difference in tasting evaluation ranged from 0.1 (with a scheme of $3.0 \times 2.0 \mathrm{~m}$ ) to 0.7 (with a landing scheme of $2.5 \times 1.5 \mathrm{~m}$ ). The most stable in quality Were the samples from grapes with three-meter spacing (7.8-8.0 points). The most stable quality of wine materials was observed from a grapes at vine planting scheme of $3.0 \times 1.0-$ the range of fluctuations with an increase in bush load from 40 to 70 thousand pcs / ha was 0.1 points with a maximum value of 8.0 with a load of 50 thousand pes / ha.

Key words: AMPELOCENOSIS, PLANTING SCHEME, GRAPE VARIETY, BUSH'S LOAD, PRODUCTIVITY, QUALITY

\section{Введение. Виноград обладает биологическими особенностями и} свойствами индивидуальными для каждого сорта. Наиболее ценными из них являются адаптивный и продукционный потенциал, устойчивость к 
биотическим и абиотическим стрессорам, продуктивность, качественные показатели винограда и вина [1-2].

На реализацию биологических хозяйственно ценных признаков сорта наиболее сильное влияние оказывают агротехнологии - форма кустов, схема и плотность их посадки, регламенты обрезки и нагрузка побегами и урожаем [3-5]. У каждого сорта должна быть своя сорт-ориентированная технология, обеспечивающая наиболее полное и эффективное использование ресурсного потенциала агротерритории, биологических свойств, стабильное плодоношение и урожайность растений, а также высокое качество винопродукции. Кроме того, происходящие изменения климатических условий в наибольшей степени оказывают влияние в целом на виноградарство, в частности повышается антропогенная нагрузка на ампелоценозы [6-10].

Гармонизация факторов среды обитания, биологических особенностей растения и агротехнологии в ампелоценозе является основным условием эффективного производства винограда [11-14]. В связи с этим изучение влияния плотности насаждений, схемы посадки и нагрузки куста побегами на продуктивность винограда и качество вина является актуальным направлением исследований.

Цель работы - установить оптимальную схему посадки виноградных растений сорта Рислинг рейнский и нагрузку куста побегами, выявить зависимость продуктивности, качественных показателей винограда и вина от применяемой агротехнологии в условиях локального изменения климата.

Объекты и методы исследований. Объектами исследований служили виноградные растения сорта Рислинг рейнский, произрастающие в Черноморской агроэкологической зоне Краснодарского края, а также урожай винограда и винопродукция, получаемая из него.

Для проведения экспериментальных исследований был заложены два полевых стационарных опыта: 
1. Изучение влияния схемы посадки на продуктивность виноградного куста, качество винограда и винопродукии. Опыт заложен в 2014 году в условиях недостаточного увлажнения на перегнойно-карбонатных почвах в ОПХ АЗОСВиВ (пригород г.-к. Анапа) на сорте Рислинг рейнский по полной двухфакторной схеме. Первый фактор - ширина междурядий: 3,5; 3,0 и 2,5 м; второй фактор - межкустное расстояние 2,0; 1,5 и 1,0 м. Форма кустов - спиралевидный двусторонний кордон АЗОС. Содержание почвы в насаждениях - по типу чёрного пара.

2. Изучение влияния нагрузки кустов побегами на продуктивность и качество винограда и винопродукиии. Опыт заложен в 2018 году в условиях недостаточного увлажнения на перегнойно-карбонатных почвах в ОПХ АЗОСВиВ (пригород г.-к. Анапа) на сорте Рислинг рейнский. Схемы посадки кустов: $3,0 \times 2,0 ; 3,0 \times 1,5 ; 3,0 \times 1,0$. Нагрузка - 40000, 50000, 60000 и 70000 побегов на гектар. Форма кустов - спиралевидный двусторонний кордон АЗОС. Содержание почвы в насаждениях - по типу чёрного пара.

В работе были использованы аналитический, полевой и лабораторный методы исследований:

- изучение закладки эмбриональных соцветий в почках зимующих глазков по методике Диканя [15];

- агробиологические учёты и учеты урожая винограда по общепринятой методике ВНИИВиВ им. Я.И. Потапенко [16];

- качество винопродукции после выработки виноматериалов методом микровиноделия по общепринятым в виноделии методикам и ГОСТам [17];

- дисперсионный, корреляционный и регрессионный анализ по Б.А. Доспехову [18].

Обсуждение результатов. Чтобы добиться устойчивого плодоношения, необходимо обеспечить биологически обоснованное сочетание агроприёмов, определяющих структуру насаждений на виноградниках, плотность и схему посадки, нагрузку кустов побегами. 
В период проведения исследований (2018 год) фаза активного роста ягод винограда (август) совпала с аномальным проявлением погодных условий: при полном отсутствии атмосферных осадков максимальная температура воздуха поднималась до отметки $36^{\circ} \mathrm{C}$. В этих стрессовых условиях наибольшая урожайность была в насаждениях с трёхметровыми междурядьями, наименьшая - в разреженных $(3,5 \times 2,0-1,0$ м) и уплотненных $(2,5 \times 2,0-1,0$ м). Под влиянием погодных аномалий наблюдалось значительное уменьшение средней массы грозди и снижение урожая винограда в вариантах с междурядьями 2,5 и 3,5 метра.

На участках с разной шириной междурядий наибольший урожай винограда чаще всего был при среднем и наименьшем межкустном расстоянии. На участках с шириной междурядий 3,5 и 3,0 м максимальная урожайность была при межкустном расстоянии 1,0 м - 8,1 и 15,4 т/га соответственно (табл. 1).

Таблица 1 - Урожай винограда на участках с разной схемой посадки кустов, АЗОСВиВ, сорт Рислинг рейнский, 2018 г., нагрузка кустов 50 тыс. побегов/га

\begin{tabular}{|c|c|c|c|c|c|}
\hline $\begin{array}{c}\text { Схема } \\
\text { посадки } \\
\text { кустов, м }\end{array}$ & $\begin{array}{c}\text { Плотность } \\
\text { размещения } \\
\text { кустов, шт./га }\end{array}$ & $\begin{array}{c}\text { Количество } \\
\text { гроздей, } \\
\text { шт./куст }\end{array}$ & $\begin{array}{c}\text { Масса } \\
\text { грозди, г }\end{array}$ & $\begin{array}{c}\text { Урожай } \\
\text { винограда, } \\
\text { кг/куст }\end{array}$ & $\begin{array}{c}\text { Урожай } \\
\text { винограда, } \\
\text { т/га }\end{array}$ \\
\hline $3,5 \times 2,0$ & 1428 & 35,5 & 70,4 & 2,5 & 3,2 \\
\hline $3,5 \times 1,5$ & 1904 & 40,0 & 59,3 & 2,37 & 4,5 \\
\hline $3,5 \times 1,0$ & 2857 & 43,5 & 64,9 & 2,83 & 8,1 \\
\hline $3,0 \times 2,0$ & 1666 & 66,0 & 108,9 & 7,2 & 11,9 \\
\hline $3,0 \times 1,5$ & 2222 & 46,0 & 126,1 & 5,8 & 12,9 \\
\hline $3,0 \times 1,0$ & 3333 & 39,0 & 119,7 & 4,6 & 15,4 \\
\hline $2,5 \times 2,0$ & 2000 & 40,5 & 79,0 & 3,2 & 6,4 \\
\hline $2,5 \times 1,5$ & 2666 & 52,5 & 66,7 & 3,5 & 9,3 \\
\hline $2,5 \times 1,0$ & 5000 & 29,0 & 56,0 & 1,63 & 6,5 \\
\hline
\end{tabular}


Плодоводство и виноградарство Юга России № 58(04), 2019 г.

Для повышения продуктивности и устойчивости плодоношения винограда дополнительно был заложен опыт по изучению влияния нагрузки кустов побегами на продуктивность насаждений, качество винограда и вина. На каждом участке со схемой посадки кустов $3,0 \times 2,0 ; 3,0 \times 1,5 ; 3,0 \times 1,0$ м испытывали по четыре нормы нагрузки кустов побегами: 40; 50; 60 и 70 тыс. шт./га.

Согласно агробиологическим учётам доля плодоносных побегов во всех вариантах опыта превышала отметку 92,1 \%. В таблице 2 представлены показатели, характеризующие плодоносность побегов по схемам посадки и величине нагрузки кустов. Коэффициенты плодоношения (К1) и плодоносности (К2) варьируют по вариантам нагрузок в значительных пределах. Низкие показатели отмечены в вариантах с повышенной нагрузкой (60-70 тыс. побегов на гектар). Независимо от плотности посадки кустов в ряду коэффициенты плодоношения не превышали отметку 2,08.

В зависимости от схемы посадки и нагрузки кустов побегами изменение показателей коэффициентов плодоношения и плодоносности по вариантам опыта не носит закономерного характера. Это даёт основание полагать, что изменение показателей плодоношения мало связано с влиянием вариантов опыта, а больше обусловлено биологией сорта, состоянием куста, ростовыми процессами и погодно-климатическими условиями места произрастания винограда. Знание уровней коэффициентов плодоношения и плодоносности в конкретных условиях произрастания сорта актуально для прогноза урожая винограда и корректировки нагрузки кустов побегами.

Склонность растений к образованию в основном плодоносных побегов с высоким коэффициентом плодоносности обеспечивает высокую урожайность кустов сорта Рислинг рейнский. Как свидетельствуют наблюдения, средний уровень урожайности сорта по вариантам опыта был неодинаковым и зависел от нагрузки куста побегами. На участке со схемой посадки кустов 3,0×2,0 м урожайность варьировала от 9,79 до 11,92 т/га, 
Плодоводство и виноградарство Юга России № 58(04), 2019 г.

со схемой посадки 3,0×1,5 м - от 8,0 до 12,0 т/га, со схемой посадки 3,0×1,0 м - от 10,08 до 15,0 т/га. В группе со схемой посадки кустов по схеме 3,0×1,5 м увеличение урожая было прямо пропорционально числу побегов на куст: количество побегов возрастает в 1,5 раза - урожай увеличивается в 1,6 раза. Повышение уровня урожайности в этом варианте в значительной мере было обеспечено увеличением средней массы грозди по сравнению с другими вариантами.

Таблица 2 - Влияние нагрузки кустов побегами на продуктивность винограда, АЗОСВиВ, сорт Рислинг рейнский, 2018 г.

\begin{tabular}{|c|c|c|c|c|c|c|c|c|c|}
\hline 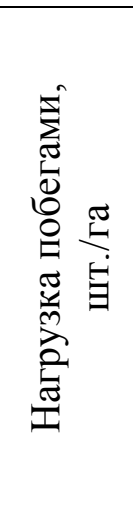 & 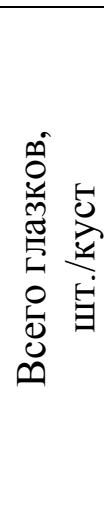 & 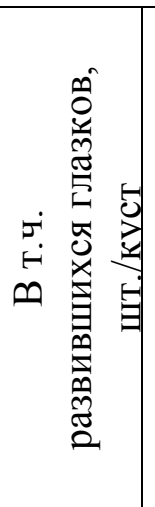 & 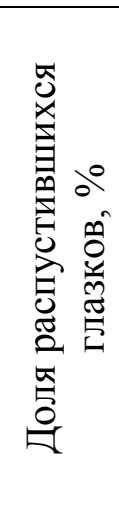 & 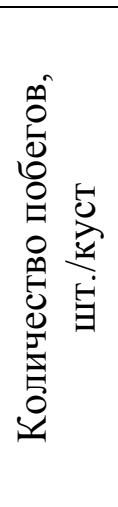 & 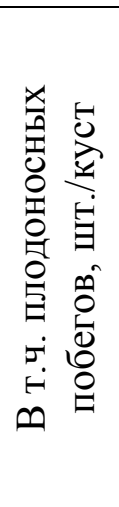 & 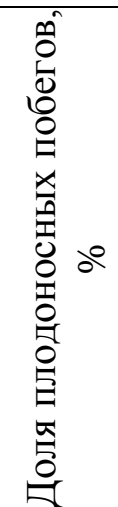 & 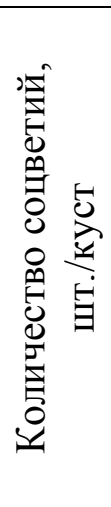 & $\vec{y}$ & $\widehat{s}$ \\
\hline \multicolumn{10}{|c|}{$3,0 \times 2,0 \mathrm{M}$} \\
\hline 40 & 24 & 24 & 100 & 24 & 24 & 100 & 63,4 & 2,64 & 2,64 \\
\hline 50 & 30 & 30 & 100 & 30 & 30 & 100 & 74,4 & 2,48 & 2,48 \\
\hline 60 & 36 & 36 & 100 & 36 & 35,8 & 100 & 79,0 & 2,21 & 2,21 \\
\hline 70 & 41,8 & 41,8 & 100 & 41,8 & 40,6 & 97,1 & 84,6 & 2,08 & 2,08 \\
\hline $\mathrm{HCP}_{05}$ & & & & 3,8 & 3,7 & & 23,1 & 0,7 & 0,7 \\
\hline \multicolumn{10}{|c|}{$3,0 \times 1,5 \mathrm{M}$} \\
\hline 40 & 22 & 18 & 80,4 & 18 & 18 & 100 & 33,4 & 186 & 1,86 \\
\hline 50 & 26 & 23 & 88,5 & 23 & 23 & 100 & 51,0 & 2,22 & 2,22 \\
\hline 60 & 31 & 27 & 86,3 & 27 & 27 & 100 & 54,0 & 2,01 & 2,03 \\
\hline 70 & 35 & 32 & 91,3 & 32 & 29 & 92,1 & 48,0 & 1,52 & 1,66 \\
\hline $\mathrm{HCP}_{05}$ & & & & 3,4 & 3,1 & & 4,2 & 0,8 & 0,7 \\
\hline \multicolumn{10}{|c|}{$3,0 \times 1,0 \mathrm{M}$} \\
\hline 40 & 17 & 12 & 70,1 & 12 & 12 & 100,0 & 21,6 & 1,77 & 1,77 \\
\hline 50 & 17 & 15 & 88,2 & 15 & 14 & 96,0 & 29,8 & 1,99 & 2.13 \\
\hline 60 & 20 & 18 & 90.0 & 18 & 18 & 98,9 & 41,0 & 2,28 & 2,30 \\
\hline 70 & 21 & 21 & 100.0 & 21 & 20 & 100,0 & 40,8 & 1.94 & 2,04 \\
\hline $\mathrm{HCP}_{05}$ & & & & 2,7 & 2,7 & & 4,3 & 0,5 & 0,7 \\
\hline
\end{tabular}


Плодоводство и виноградарство Юга России № 58(04), 2019 г.

Увеличение продуктивности в вариантах широкорядных посадок не прямо пропорционально росту числа побегов. Уровень урожайности увеличился всего в 1,2 раза, а количество побегов в 1,75 раз. Аналогичные изменения урожайности зафиксированы в группе загущённых посадок 3,0×1,0 м: число побегов возрастает в 1,75 раз - урожайность увеличивается в среднем в 1,5 раза.

Следует отметить, во всех вариантах опыта по продуктивности насаждений выделился вариант с нагрузкой 50 тыс. шт. побегов на гектар. Здесь зафиксированы самая высокая масса грозди $(108,9 ; 126,1 ; 119,7$ г.) и урожай $(11,92 ; 12,90 ; 15,43$ т/га) (табл. 3).

Таблица 3 - Урожай винограда Рислинг рейнский в зависимости от нагрузки кустов побегами, АЗОСВиВ, 2018 г.

\begin{tabular}{|c|c|c|c|c|c|}
\hline 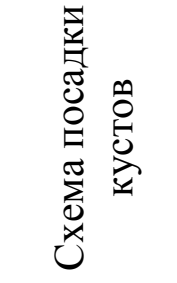 & 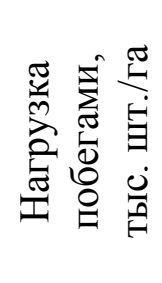 & 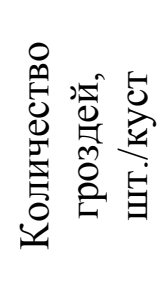 & 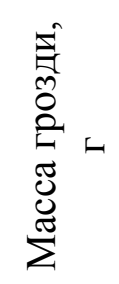 & 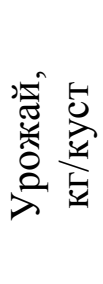 & 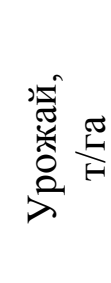 \\
\hline $3,0 \times 2,0$ & $\begin{array}{l}40 \\
50 \\
60 \\
70 \\
\end{array}$ & $\begin{array}{l}56 \\
66 \\
74 \\
82\end{array}$ & $\begin{array}{c}103,2 \\
108,9 \\
90,2 \\
86,3\end{array}$ & $\begin{array}{l}5,9 \\
7,2 \\
6,6 \\
7,0\end{array}$ & $\begin{array}{c}9,79 \\
11,92 \\
11,06 \\
11,71\end{array}$ \\
\hline Среднее & & 69 & 97,2 & 6,7 & 11,12 \\
\hline $\mathrm{HCP}_{05}$ & & & 4,5 & 1,1 & 1,4 \\
\hline $3,0 \times 1,5$ & $\begin{array}{l}40 \\
50 \\
60 \\
70\end{array}$ & $\begin{array}{l}33 \\
46 \\
46 \\
44\end{array}$ & $\begin{array}{c}109,3 \\
126,1 \\
84,8 \\
88,6\end{array}$ & $\begin{array}{l}3,6 \\
5,8 \\
3,9 \\
3,9\end{array}$ & $\begin{array}{c}8,00 \\
12,90 \\
8,67 \\
8,67\end{array}$ \\
\hline Среднее & & 42 & 102,2 & 4,3 & 9,56 \\
\hline $\mathrm{HCP}_{05}$ & & & 6,1 & 1,4 & 2,1 \\
\hline $3,0 \times 1,0$ & $\begin{array}{l}40 \\
50 \\
60 \\
70\end{array}$ & $\begin{array}{l}34 \\
39 \\
33 \\
41\end{array}$ & $\begin{array}{c}88,6 \\
119,7 \\
117,2 \\
94,8\end{array}$ & $\begin{array}{l}3,0 \\
4,6 \\
3,8 \\
4,0\end{array}$ & $\begin{array}{l}10,08 \\
15,43 \\
12,50 \\
13,25\end{array}$ \\
\hline Среднее & & 36,7 & 105,0 & 3,8 & 12,81 \\
\hline $\mathrm{HCP}_{05}$ & & & 5,5 & 1,1 & 2,1 \\
\hline
\end{tabular}


Изучение динамики накопления сахаров необходимо для выбора оптимальных сроков уборки винограда в целях получения высококачественной продукции [19-20]. В агроэкологических условиях 2018 года при высокой инсоляции и дефиците атмосферных осадков изучена динамика накопления сахаров в ягодах винограда. В начале созревания накопление сахаров проходило более интенсивно в насаждениях со схемой посадки кустов $3,0 \times 1,0$ м, однако к моменту уборки урожая в этом варианте опыта была отмечена наименьшая концентрация сахаров $(17,2$ г/100 см³). В период уборки урожая самая высокая сахаристость была в варианте опыта $3,0 \times 1,5 \mathrm{~m}-18,8$ г/100 $\mathrm{cm}^{3}$ (рис. 1 ).

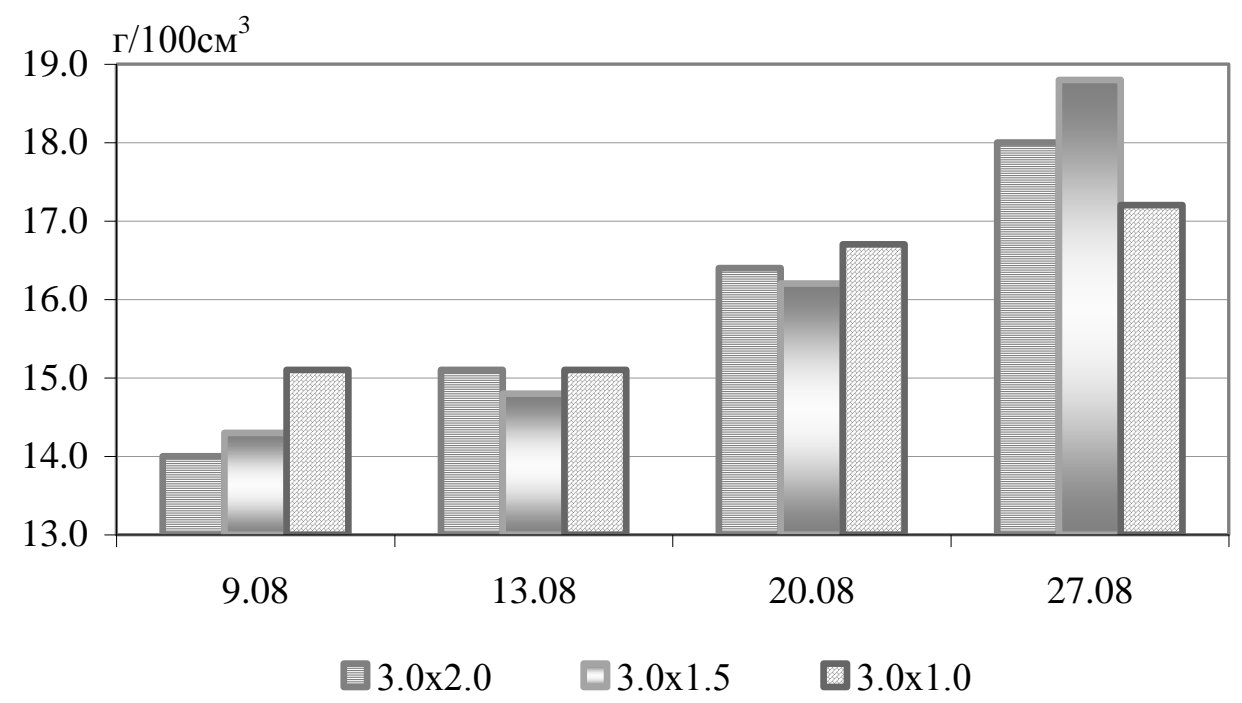

Рис. 1. Динамика накопления сахаров в ягодах винограда сорта Рислинг рейнский, АЗОСВиВ, 2018 г.

Среднее значение массовой концентрации сахаров в винограде на участке с разной схемой посадки кустов за 2016-2017 годы находилось в диапазоне от 17,9 до 20,9 г/100 $\mathrm{cm}^{3}$, титруемых кислот - от 6,41 до 7,20 г/дм³. Виноград выделившихся по урожайности вариантов опыта с трехметровыми междурядьями имел в 2016-2017 годах самые высокие качественные показатели - 18,7-22,4 г/100 см³ сахаров и 5,89-7,36 г/дм³ титруемых кислот (табл. 4). 
Таблица 4 - Качество винограда сорта Рислинг рейнский при различной схеме посадки кустов, АЗОСВиВ

\begin{tabular}{|c|c|c|c|c|c|c|}
\hline \multirow{2}{*}{$\begin{array}{c}\text { Схема } \\
\text { посадки, м }\end{array}$} & \multicolumn{3}{|c|}{$\begin{array}{c}\text { Массовая концентрация } \\
\text { сахаров, г/100 см }\end{array}$} & \multicolumn{3}{c|}{ Титруемая кислотность, г/дм ${ }^{3}$} \\
\cline { 2 - 7 } & 2016 г & 2017 г & среднее & 2016 г & 2017 г & среднее \\
\hline $3,5 \times 2,0$ & 17,1 & 18,7 & 17,9 & 6,43 & 7,52 & 6,98 \\
\hline $3,5 \times 1,5$ & 17,6 & 18,4 & 18,0 & 6,65 & 7,35 & 7,00 \\
\hline $3,5 \times 1,0$ & 19,4 & 18,6 & 19,0 & 6,72 & 7,68 & 7,20 \\
\hline $3,0 \times 2,0$ & 19,4 & 22,4 & 20,9 & 6,44 & 7,14 & 6,79 \\
\hline $3,0 \times 1,5$ & 18,7 & 18,8 & 18,8 & 6,63 & 7,36 & 7,00 \\
\hline $3,0 \times 1,0$ & 19,3 & 19,8 & 19,6 & 5,89 & 6,93 & 6,41 \\
\hline $2,5 \times 2,0$ & 19,8 & 18,4 & 19,1 & 5,40 & 7,76 & 6,58 \\
\hline $2,5 \times 1,5$ & 19,9 & 19,2 & 19,6 & 6,36 & 7,87 & 7,12 \\
\hline $2,5 \times 1,0$ & 19,1 & 18,9 & 19,0 & 6,21 & 7,66 & 6,94 \\
\hline
\end{tabular}

Из урожая винограда методом микровиноделия были выработаны столовые сухие виноматериалы и проведен их физико-химический анализ (табл. 5). Массовая концентрация сахаров, летучих кислот и диоксида серы во всех образцах находились в пределах требований ГОСТ 32030-2013 «Вина столовые и виноматериалы столовые. Общие технические условия», предъявляемых для столовых сухих вин и виноматериалов.

Таблица 5 - Основные физико-химические показатели опытных виноматериалов, АЗОСВиВ, Рислинг рейнский

\begin{tabular}{|c|c|c|c|c|c|c|c|c|c|}
\hline \multirow{3}{*}{$\begin{array}{c}\text { Схема } \\
\text { посадки, } \\
\text { м }\end{array}$} & \multirow{2}{*}{\multicolumn{3}{|c|}{$\begin{array}{c}\text { Объемная доля } \\
\text { этилового спирта, \% }\end{array}$}} & \multicolumn{6}{|c|}{ Массовая концентрация, г/дм ${ }^{3}$} \\
\hline & & & & \multicolumn{3}{|c|}{ титруемых кислот } & \multicolumn{3}{|c|}{$\begin{array}{c}\text { приведенного } \\
\text { экстракта }\end{array}$} \\
\hline & $\frac{\mathfrak{b}}{\stackrel{2}{0}}$ & 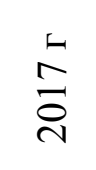 & 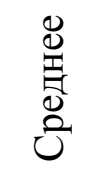 & $\begin{array}{l}\text { bे } \\
\text { ¿ }\end{array}$ & $\frac{\sqrt{2}}{\stackrel{2}{2}}$ & 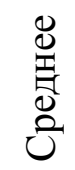 & $\underset{b}{b}$ & 혼 & 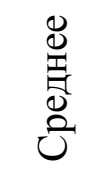 \\
\hline $3,5 \times 2,0$ & 10,2 & 11,2 & 10,7 & 7,5 & 8,4 & 8,0 & 20,0 & 21,9 & 21,0 \\
\hline $3,5 \times 1,5$ & 10,5 & 11,0 & 10,7 & 7,7 & 8,0 & 7,9 & 20,3 & 21,1 & 20,7 \\
\hline $3,5 \times 1,0$ & 11,6 & 11,1 & 11,4 & 7,4 & 8,2 & 7,8 & 19,1 & 22,6 & 20,8 \\
\hline $3,0 \times 2,0$ & 11,6 & 13,3 & 12,4 & 7,5 & 8,1 & 7,8 & 19,5 & 24,5 & 22,0 \\
\hline $3,0 \times 1,5$ & 11,1 & 11,1 & 11,1 & 7,3 & 7,9 & 7,6 & 19,1 & 22,1 & 20,6 \\
\hline $3,0 \times 1,0$ & 11,5 & 11,8 & 11,6 & 6,7 & 7,8 & 7,3 & 17,7 & 21,8 & 19,7 \\
\hline $2,5 \times 2,0$ & 11,9 & 11,0 & 11,5 & 7,5 & 7,9 & 7,7 & 18,6 & 22,7 & 20,7 \\
\hline $2,5 \times 1,5$ & 11,9 & 11,5 & 11,7 & 7,6 & 8,0 & 7,8 & 18,5 & 20,9 & 19,7 \\
\hline $2,5 \times 1,0$ & 11,4 & 11,3 & 11,3 & 6,8 & 8,3 & 7,6 & 17,6 & 22,8 & 20,2 \\
\hline
\end{tabular}


Объёмная доля этилового спирта, в среднем за годы исследований, колебалась от 10,7 до 12,4 \%. В образце опытного виноматериала при схеме посадки виноградных растений $3,0 \times 1,5$ этот показатель был стабильным из года в год и составлял $11,1 \%$.

Массовая концентрация титруемых кислот была максимальной при ширине междурядий 3,5 метра: в среднем 7,8-8,0 г/дм³. Минимальные значения были отмечены в образцах со схемой посадки растений $3,0 \times 1,0$ м; $3,0 \times 1,5$ м и $2,5 \times 1,0$ м - от 7,3 до 7,6 г/дм³.

Массовая концентрация приведённого экстракта, определяющего полноту вкуса, была высока во всех опытных вариантах - в среднем от 19,7 до 22,0 г/дм³ , что на 3,7-6,0 г/дм³ выше минимальных требований ГОСТ.

Дегустационная оценка опытных виноматериалов осуществлялась дегустационной комиссией СКФНЦСВВ по 10-ти балльной шкале. Из полученных результатов видно, что 2017 год был наиболее удачным для всех вариантов опыта. В сравнении с 2016 годом разница в дегустационной оценке составляла от 0,1 (при схеме 3,0×2,0 м) до 0,7 (при схеме посадки $2,5 \times 1,5$ м). Наиболее стабильными по качеству были опытные виноматериалы из винограда с трехметровыми междурядьями - их дегустационная оценка в среднем составляла 7,8-8,0 баллов.

По заключению дегустационной комиссии, образцы столовых сухих виноматериалов Рислинг рейнский урожая 2016 года со схемой посадки $3,5 \times 2,0$ м; $3,0 \times 1,5$ м и $3,0 \times 1,0$ м отличались ярким сортовым ароматом с цитронными тонами, полным развитым вкусом с гармоничной кислотностью.

Среди виноматериалов урожая 2017 года высоким качеством обладали образцы со схемой посадки кустов винограда $3,5 \times 2,0$ м; 3,5×1,0 м; $3,0 \times 1,5$ м; 2,5×1,0 м и 2,5×2,0 м - в них отмечали сортовой аромат с преобладанием цветочных оттенков и полный вкус с приятной свежестью. Особенно выделились виноматериалы при схеме посадки $3,0 \times 1,0$ м (8,2 балла) и $2,5 \times 1,5$ м (8,3 балла), в их аромате наряду с цветочными тонами иденти- 
фицировались оттенки свежескошенного сена, а во вкусе были отмечены гармоничность и полнота (рис. 2).

Для установления влияния нагрузки куста побегами на качество винопродукции опытные образцы виноматериалов были оценены дегустационной комиссией по 10-ти балльной шкале (рис. 3). Максимальную оценку получили образцы с нагрузкой кустов винограда 50 тыс. побегов на гектар при схеме посадки 3,0×1,0 и 60 тыс. побегов на гектар при схеме посадки $3,0 \times 2,0$.

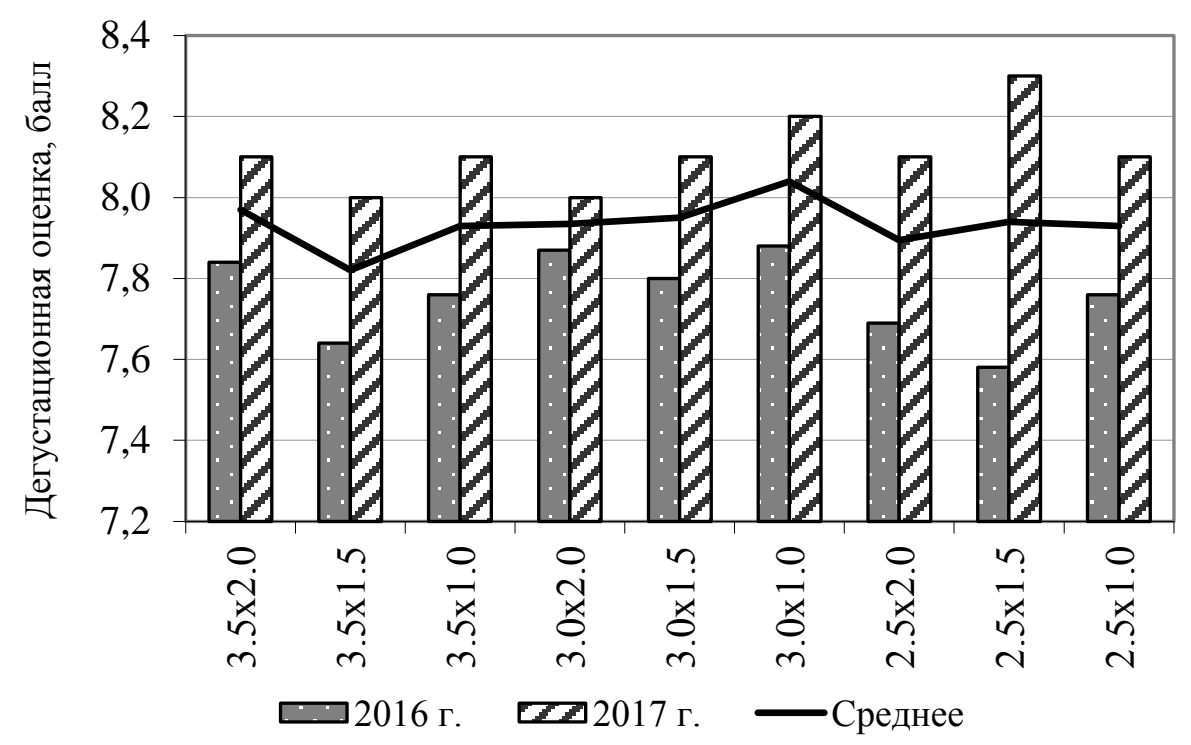

Рис. 2. Дегустационная оценка опытных виноматериалов из винограда сорта Рислинг рейнский, АЗОСВиВ, 2016-2017 гг.

При увеличении нагрузки кустов до 60 тыс. шт. побегов /га, при схеме посадки 3,0×2,0, дегустационная оценка виноматериалов возрастает до 8,0 баллов и далее снижается. При схеме посадки $3,0 \times 1,5$ качество виноматериалов выше из винограда с нагрузкой кустов 40 и 50 тыс. побегов на гектар - 7,9 балла, а при дальнейшем повышении нагрузки дегустационная оценка снижается.

Наиболее стабильное качество винопродукции было при схеме посадки винограда 3,0×1,0: диапазон колебаний при увеличении нагрузки ку- 
ста побегами составил 0,1 балла с максимальным значением 8,0 при нагрузке 50 тыс. шт./га.

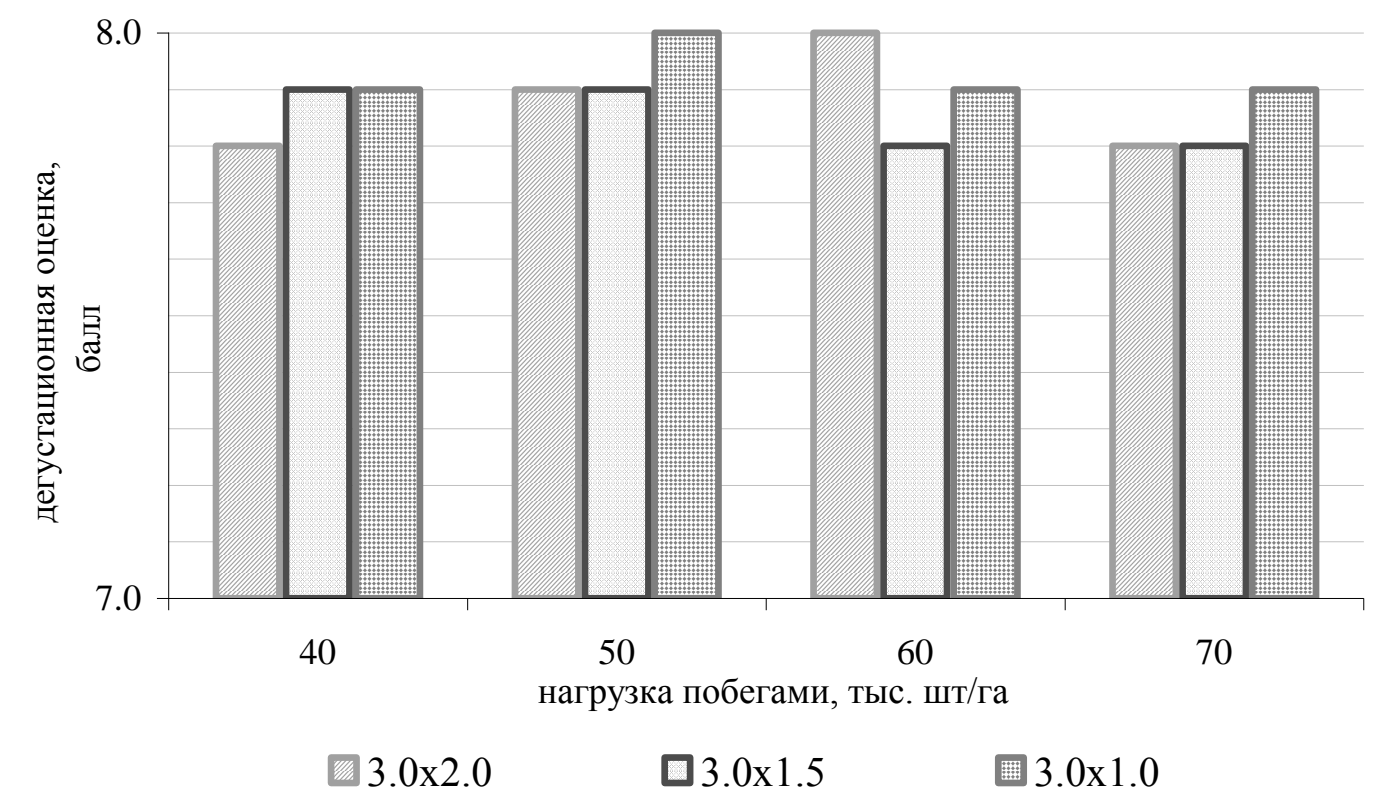

Рис. 3. Зависимость дегустационной оценки от нагрузки куста побегами, АЗОСВиВ, сорт Рислинг рейнский, схема посадки $3,0 \times 2,0 ; 3,0 \times 1,5$ и $3,0 \times 1,0,2018$ г.

Bbывды. В стрессовых условиях 2018 года наибольшая хозяйственная продуктивность зафиксирована в насаждениях винограда сорта Рислинг рейнский с трёхметровыми междурядьями, наименьшая - в разреженных $(3,5 \times 2,0-1,0$ м) и уплотненных $(2,5 \times 2,0-1,0$ м). Под влиянием погодных аномалий наблюдалось значительное уменьшение средней массы грозди и снижение урожая винограда в вариантах опыта с междурядьями 2,5 и 3,5 метра.

По продуктивности насаждений выделился вариант с нагрузкой 50 тыс. шт. побегов на гектар. Здесь зафиксирована самая высокая масса грозди $(108,9 ; 126,1 ; 119,7$ г) и максимальная урожайность $(11,92 ; 12,90 ; 15,43$ т/га).

В стрессовых условиях 2018 года, при высокой инсоляции и дефиците атмосферных осадков, в начале созревания ягод накопление сахаров проходило более интенсивно в насаждениях со схемой посадки кустов $3,0 \times 1,0$ м, однако к моменту уборки в этом варианте опыта была отмечена наименьшая 
концентрация сахаров - 17,2 г/100 cм³. В период уборки урожая максимальная сахаристость была в варианте опыта 3,0×1,5 м-18,8 г/100 см³.

Показано, что 2017 год был наиболее благоприятным для получения высококачественной продукции по всем вариантам опыта. В сравнении с 2016 годом разница в дегустационной оценке составляла от 0,1 (при схеме 3,0×2,0 м) до 0,7 (при схеме посадки 2,5×1,5 м). Наиболее стабильными по качеству были образцы из винограда с трёхметровыми междурядьями, их дегустационная оценка в среднем составляла 7,8-8,0 баллов.

Установлено, что в погодно-климатических условиях 2018 года нагрузка 50 тыс. побегов на гектар при схеме посадки 3,0×1,0 и 60 тыс. побегов при схеме 3,0×2,0 даёт возможность получить высококачественную продукцию. Наиболее стабильное качество виноматериалов отмечено при схеме посадки 3,0×1,0, диапазон колебаний при увеличении нагрузки от 40 до 70 тыс. побегов/га составил 0,1 балла с максимальным значением 8,0 при нагрузке 50 тыс. шт./га.

\section{Литература}

1. Адаптивный и продукционный потенциал генофонда винограда в нестабильных условиях умеренно континентального климата юга России / В.С. Петров, Н.И. Ненько, И.А. Ильина, Е.Т. Ильницкая, М.А. Сундырева, Ю.Ф. Якуба // Вестник российской сельскохозяйственной науки. 2017. № 4. С. 25-29.

2. Виноградарство / под ред. А.К. Раджабова. М.: ФГБНУ «Росинформагротех», 2017. $500 \mathrm{c}$.

3. Гусейнов Ш.Н., Чигрик Б.В. Эффективные способы ведения и формирования виноградных кустов в условиях юга России (рекомендации). Новочеркасск: ВНИИВиВ им. Я.И. Потапенко Россельхозакадемии, 2013. 37 с.

4. Penkov M. Influence of Groving Location on the Quality of Grape and Wines from Various Vine Cultivars // Почвознан. Агрохим. Екол. - 2007. - Vol. 42, № 4. Р. 44-53. (Болг.).

5. Andrea Anesi, Vineyard zone delineation by cluster classification based on annual grape and vine characteristics/ Andrea Anesi, Matteo Stocchero, Silvia Dal Santo, Mauro Commisso, Sara Zenoni, Stefania Ceoldo, Giovanni Battista Tornielli, Tracey E. Siebert, Markus Herderich, Mario Pezzotti, Flavia Guzzo // Precision Agriculture, 2017, Volume 18, Issue 4, pp 525-573

6. C. van Leeuwen, Terroir: the effect of the physical environment on vine growth, grape ripening and wine sensory attributes/Managing Wine Quality Viticulture and Wine Quality, 2010, Pages 273-315 
7. Ramón Mira de Orduña, Climate change associated effects on grape and wine quality and production. Food Research International Volume 43, Issue 7, August 2010, Pages 1844-1855

8. José Mariano Escalona Responses of leaf night transpiration to drought stress in Vitis vinifera L. /Sigfredo Fuentes, Magdalena Tomás, Sebastià Martorell, Jaume Flexas, Hipólito Medrano//Agricultural Water Management Volume 118, February 2013, Pages 50-58

9. C. Lovisolo, I. Perrone, A. Carra, A. Ferrandino, J. Flexas, H. Medrano, A. Schubert Drought-induced changes in development and function of grapevine (Vitis spp.) organs and in their hydraulic and non-hydraulic interactions at the whole-plant level: a physiological and molecular update Funct. Plant Biol., 37 (2010), pp. 98-116 Reynolds et al., 1996

10. Cozzolino D., Cynkar W., Dambergs R., Smith P. Two-dimensional correlation analisis of the effect of temperature on the fingerprint of wines analised by mass spectrometry electronic nose. Sensors and Actuators B: Chemical. 2010. T. 145. № 2. pp. 628-634.

11. A G Reynolds, D A Wardle, A P Naylor Impact of training system, vine spacing, and basal leaf removal on Riesling, vine performance, berry composition, canopy microclimate, and vineyard labor requirements American Journal of Enology and Viticulture, 47 (1996), pp. 63-76

12. Дергунов, А.В. Зависимость продуктивности винограда и качества вин от схемы посадки // Политематический сетевой электронный научный журнал Кубанского государственного аграрного университета. 2017. № 132. С. 1155-1165.

13. Andrea Anesi, Towards a scientific interpretation of the terroir concept: plasticity of the grape berry metabolome / Andrea Anesi, Matteo Stocchero, Silvia Dal Santo and other // BMC Plant Biology, 2015

14. Зармаев А.А. Научные основы адаптивного виноградарства. Махачкала: Юпитер, 2000 г. 344 с.

15. Дикань Л.П. Формирование плодоносности и урожая виноградного куста. Киев. Изд-во УСХА.1991. 215 с.

16. Агротехнические исследования по созданию интенсивных виноградных насаждений на промышленной основе. Новочеркасск, 1978.173 с.

17. Методическое и аналитическое обеспечение организации и проведения исследований по технологии производства винограда. Краснодар: ГНУ СКЗНИИСиВ, 2010. 182 c.

18. Доспехов Б.А. Методика полевого опыта. М.: Агропромиздат, 1985. 351 с.

19. Jakobovic S., Jeromel A., Jakodovic M. Grape maturity of Rhein Riesling cultivar and synthesis of atypical ageing aroma precursors. Agriculture.-2014.-Vol.20, № 2.-pp. 29-35

20. Влияние схемы посадки на биохимический состав белых столовых виноматериалов из сорта Рислинг рейнский / А.А. Ширшова, Т.И. Гугучкина, Т.П. Павлюкова, В.С. Петров, А.В. Прах // Виноделие и виноградарство. 2016. № 2. С. 18-23.

\section{References}

1. Adaptivnyj i produkcionnyj potencial genofonda vinograda v nestabil'nyh usloviyah umerenno kontinental'nogo klimata yuga Rossii / V.S. Petrov, N.I. Nen'ko, I.A. Il'ina, E.T. Il'nickaya, M.A. Sundyreva, Yu.F. Yakuba // Vestnik rossijskoj sel'skohozyajstvennoj nauki. 2017. № 4. S. 25-29.

2. Vinogradarstvo / pod red. A.K. Radzhabova. M.: FGBNU «Rosinformagrotekh», 2017. $500 \mathrm{~s}$. 
3. Gusejnov Sh.N., Chigrik B.V. Effektivnye sposoby vedeniya i formirovaniya vinogradnyh kustov v usloviyah yuga Rossii (rekomendacii). Novocherkassk: VNIIViV im. Ya.I. Potapenko Rossel'hozakademii, 2013. 37 s.

4. Penkov M. Influence of Groving Location on the Quality of Grape and Wines from Various Vine Cultivars // Pochvoznan. Agrohim. Ekol. - 2007. - Vol. 42, № 4. R. 44-53. (Bolg.).

5. Andrea Anesi, Vineyard zone delineation by cluster classification based on annual grape and vine characteristics/ Andrea Anesi, Matteo Stocchero, Silvia Dal Santo, Mauro Commisso, Sara Zenoni, Stefania Ceoldo, Giovanni Battista Tornielli, Tracey E. Siebert, Markus Herderich, Mario Pezzotti, Flavia Guzzo // Precision Agriculture, 2017, Volume 18, Issue 4, pp 525-573

6. C. van Leeuwen, Terroir: the effect of the physical environment on vine growth, grape ripening and wine sensory attributes/Managing Wine Quality Viticulture and Wine Quality, 2010, Pages 273-315

7. Ramón Mira de Orduña, Climate change associated effects on grape and wine quality and production. Food Research International Volume 43, Issue 7, August 2010, Pages 1844-1855

8. José Mariano Escalona Responses of leaf night transpiration to drought stress in Vitis vinifera L. / Sigfredo Fuentes, Magdalena Tomás, Sebastià Martorell, Jaume Flexas, Hipólito Medrano // Agricultural Water Management Volume 118, February 2013, Pages 50-58.

9. C. Lovisolo, I. Perrone, A. Carra, A. Ferrandino, J. Flexas, H. Medrano, A. Schubert Drought-induced changes in development and function of grapevine (Vitis spp.) organs and in their hydraulic and non-hydraulic interactions at the whole-plant level: a physiological and molecular update Funct. Plant Biol., 37 (2010), pp. 98-116 Reynolds et al., 1996

10. Cozzolino D., Cynkar W., Dambergs R., Smith P. Two-dimensional correlation analisis of the effect of temperature on the fingerprint of wines analised by mass spectrometry electronic nose. Sensors and Actuators B: Chemical. 2010. T. 145. № 2. pp. 628-634.

11. A G Reynolds, D A Wardle, A P Naylor Impact of training system, vine spacing, and basal leaf removal on Riesling, vine performance, berry composition, canopy microclimate, and vineyard labor requirements American Journal of Enology and Viticulture, 47 (1996), pp. 63-76

12. Dergunov, A.V. Zavisimost' produktivnosti vinograda i kachestva vin ot skhemy posadki // Politematicheskij setevoj elektronnyj nauchnyj zhurnal Kubanskogo gosudarstvennogo agrarnogo universiteta. 2017. № 132. S. 1155-1165.

13. Andrea Anesi, Towards a scientific interpretation of the terroir concept: plasticity of the grape berry metabolome / Andrea Anesi, Matteo Stocchero, Silvia Dal Santo and other // BMC Plant Biology, 2015

14. Zarmaev A.A. Nauchnye osnovy adaptivnogo vinogradarstva. Mahachkala: Yupiter, 2000 g. 344 s.

15. Dikan' L.P. Formirovanie plodonosnosti i urozhaya vinogradnogo kusta. Kiev. Izd-vo USHA.1991. $215 \mathrm{~s}$.

16. Agrotekhnicheskie issledovaniya po sozdaniyu intensivnyh vinogradnyh nasazhdenij na promyshlennoj osnove. Novocherkassk, $1978.173 \mathrm{~s}$.

17. Metodicheskoe i analiticheskoe obespechenie organizacii i provedeniya issledovanij po tekhnologii proizvodstva vinograda. Krasnodar: GNU SKZNIISiV, 2010. $182 \mathrm{~s}$.

18. Dospekhov B.A. Metodika polevogo opyta. M.: Agropromizdat, 1985. $351 \mathrm{~s}$.

19. Jakobovic S., Jeromel A., Jakodovic M. Grape maturity of Rhein Riesling cultivar and synthesis of atypical ageing aroma precursors. Agriculture.-2014.-Vol.20, № 2.-pp. 29-35

20. Vliyanie skhemy posadki na biohimicheskij sostav belyh stolovyh vinomaterialov iz sorta Risling rejnskij / A.A. Shirshova, T.I. Guguchkina, T.P. Pavlyukova, V.S. Petrov, A.V. Prah // Vinodelie i vinogradarstvo. 2016. № 2. S. 18-23. 